\title{
Desain Pengembangan Kurikulum Integratif
}

\author{
Husniyatus Salamah Zainiyati \\ UIN Sunan Ampel Surabaya
}

Email: husnayatus@yahoo.com

\begin{abstract}
Implementation of an integrated curriculum in UIN Maliki seeks to provide basic competencies of Islamic sciences as a characteristic of UIN, as well as the foundation for the development of fields of study are developed on existing majors. Study program ta'lim al-afkār al-Islämiyyah and ta'lim al-Qur'ān not only discuss the matter as Fiqh, Sufism, Aqeedah, but the study needs to be developed by taking the material Qur'an and Hadith relating to the development of science and technology. Basic Islamic knowledge can be used for students or faculty development studies field according to the respective department. The program not only as a prerequisite studies program at UIN Islamic subjects, but can be used to support other subjects. Ma'had tradition intended to form the character of students and develop Islamic culture on campus.
\end{abstract}

Keyword: integrative curriculum, ma'had 'âly

\begin{abstract}
Abstrak
Implementasi kurikulum integratif di UIN Maliki Malang berupaya memberikan kompetensi dasar ilmu-ilmu keislaman sebagai ciri khas UIN, sekaligus sebagai landasan bagi pengembangan bidang-bidang studi yang dikembangkan pada jurusan yang ada. Program kajian ta'Tim al-afkār al-Islämiyyah dan ta'Tim al-Qurān tidak hanya membahas materi seperti fiqh, tasawuf, aqidah, tetapi kajian perlu dikembangkan dengan mengambil materi Quran dan Hadis yang berhubungan dengan perkembangan sains dan teknologi. Dasar ilmu keislaman tersebut dapat digunakan mahasiswa atau dosen untuk pengembangan bidang kajian sesuai dengan jurusannya masing-masing. Program kajian tidak hanya sebagai prasyarat memprogram mata kuliah keislaman di UIN, akan tetapi bisa digunakan sebagai penunjang mata kuliah lainnya. Tradisi ma'had ditujukan untuk membentuk karakter mahasiswa dan mengembangkan kultur Islami di kampus.
\end{abstract}

Kata kunci: kurikulum integratif, ma'had 'āly 


\section{A. Pendahuluan}

Perguruan tinggi dan pesantren sebenarnya memiliki akar budaya yang sama, yaitu sebagai lembaga pendidikan, hanya berbeda dalam lingkungannya. Jika perguruan tinggi dan pesantren dapat diintegrasikan dalam konteks yang integral, maka model atau sistem pendidikannya akan menjadi alternatif pengembangan pendidikan tinggi di Indonesia. Kemudian muncul pertanyaan, nilai-nilai apa saja yang dapat diambil dari pesantren, kemudian dibumikan dalam tradisi pendidikan di perguruan tinggi? Dalam hal ini, lembaga pesantren difungsikan untuk membangun tradisi yang kokoh. Tradisi yang dimaksudkan di sini adalah kebiasaan dan adat istiadat yang bernuansa Islami. Misalnya, kebiasaan melakukan salat berjamaah, tadarus al-Quran, salat malam, disiplin, menghormati sesama kolega, menghargai ilmu.

Kebutuhan untuk mengembangkan kurikulum integratif pada pendidikan tinggi Islam disebabkan oleh adanya tuntutan kebutuhan masyarakat dan perkembangan IPTEK. Sumardi menyatakan dalam suasana yang semakin kompetitif khususnya di bidang ilmu pengetahuan dan kemampuan intelektual lainnya, para sarjana IAIN adalah yang banyak menderita kekurangan. Pada umumnya pendekatan kurikuler di IAIN masih sangat doktriner dan dogmatis serta sarjana agama itu belum banyak "ber-try-out" dalam berbagai kesempatan.

Ma'arif mengungkapkan bahwa kaitan antara pendidikan Islam dan konsep Ilmu, setidak-tidaknya ada tiga persolan pokok yang saling berkaitan yang dapat dijabarkan menjadi; 1) sosok muslim yang menjadi gamang apabila dihadapkan kepada persoalan-persoalan dunia yang selalu berubah tampaknya disebabkan oleh idapan krisis identitas diri, sedangkan sistem pendidikan dan kurikulum pendidikan Islam yang sedang berlalu tidak dapat menolong keadaan; 2) kegiatan pendidikan Islam haruslah berorientasi ke arah transendental agar kegiatan itu punya makna spiritual yang mengatasi ruang dan waktu; 3) perlunya dilakukan redefinisi ulama. ${ }^{1}$

Untuk mengatasi berbagai kelemahan tersebut, maka Direktur Pendidikan Tinggi Islam (Diktis) mengambil kebijakan tentang pengembangan kurikulum PTAI, yaitu: 1) kurikulum berbasis hasil

'A Syafi'i Ma'arif, Peta Bumi Intelektualisme Islam di Indonesia, (Bandung: Mizan, 1993), hlm. 12. 
belajar; 2) kurikulum terdiri atas kurikulum inti dan kurikulum institusional; 3) kurikulum inti (40\%) ditetapkan oleh pemerintah dan berlaku secara nasional, sedangkan kurikulum institusional (60\%) ditetapkan oleh PTAI dan berlaku hanya di PTAI tersebut; 4) kurikulum secara keseluruhan (inti dan institusional) ditetapkan oleh PTAI; dan 5) kualitas kurikulum menjadi tanggung jawab PTAI. ${ }^{2}$

Kebijakan tersebut mengandung makna bahwa; 1) kurikulum perlu dikembangkan dengan lebih menitikberatkan pada pencapaian target kompetensi daripada penguasaan materi; 2) lebih mengakomodasikan keragaman kebutuhan dan sumber daya pendidikan yang tersedia; 3) memberikan kebebasan yang lebih luas kepada pelaksana pendidikan di PTAI untuk mengembangkan dan melaksanakan program pendidikan sesuai dengan kebutuhan; 4) menggunakan prinsip kesatuan dalam kebijakan dan keragaman dalam pelaksanaan. Hamalik menyatakan bahwa kebijakan yang bertujuan untuk meningkatkan angka partisipasi masyarakat dan mutu pendidikan menuntut adanya pengembangan kurikulum, sedangkan pengembangan kurikulum yang bertujuan untuk meningkatkan relevansi program pendidikan dapat dicapai melalui pengembangan kurikulum daerah dan sekolah/perguruan tinggi serta melibatkan ikut serta stakeholder. ${ }^{3}$

Berdasarkan studi pendahuluan diketahui bahwa UIN Maliki Malang merupakan salah satu PTAI yang menggunakan sistem penyelenggaraan pendidikan tinggi integratif yaitu sistem pendidikan dan tradisi di Ma'had Sunan Ampel al-Aly diintegrasikan ke dalam sistem pendidikan di UIN Maliki Malang. ${ }^{4}$ Menteri Agama RI-pada saat itu-Maftuh Basyuni juga mengacungi jempol terhadap UIN Malang. Ia mengatakan akan menerapkan program ke-ma'had-an seperti yang ada di UIN Malang pada seluruh Perguruan Tinggi Islam di Indonesia, sebagai pendukung pembelajaran mahasiswa yang berlatar belakang Islam. ${ }^{5}$ Implikasi dari sis-

${ }^{2}$ A. Furchan, dkk. Pengembangan Kurikulum Berbasis Kompetensi di PTAI, (Yogyakarta: Pustaka Pelajar, 2005), hlm. 33.

${ }^{3}$ Oemar Hamalik, Manajemen Pengembangan Kurikulum (Bandung: Rosdakarya, 2006), hlm. 4.

${ }^{4}$ Pedoman Pendidikan Universitas Islam Negeri (UIN) Malang Tahun Akademik 2006/2007, hlm. 144-145.

5 Tahap I pembangunan ma'had akan dilakukan pada 5 kota yaitu di UIN Jakarta, UINYogyakarta, IAIN Surabaya, Makasar dan Medan. Gema Media Informasi dan Kebijakan Kampus (edisi 25 November- Desember 2006), hlm. 7. 
tem pendidikan tinggi integratif tersebut, semua mahasiswa UIN Maliki Malang baik dari prodi umum maupun prodi agama pada tahun pertama diwajibkan bertempat tinggal di Ma'had UIN Maliki Malang dan mengikuti perkuliahan khusus program bahasa Arab (PKPBA) setiap hari pada pukul 14.00-20.00 WIB.

Tulisan ini akan membahas tentang bagaimana desain pengembangan kurikulum integratif pesantren mahasiswa dan UIN Maliki Malang. Penelitian ini menggunakan pendekatan deskriptif kualitatif. Pengumpulan data dihimpun dari observasi, wawancara dan dokumentasi. Data akan dianalisis melalui reduksi data, display data dan verifikasi atau kesimpulan.

\section{B. Desain Pengembangan Kurikulum Integratif Ma'had Sunan Ampel al-Aly dengan UIN Maliki Malang}

UIN Maliki Malang memanifestasikan konsep ūlul al-bāb dalam bentuk program pendidikan. A.M. Saefuddin menjelaskan bahwa ülul albāb adalah pemikir intelektual yang memiliki ketajaman analisis terhadap gejala dan proses alamiah dengan metode ilmiah induktif dan deduktif, serta intelektual yang membangun kepribadiannya dengan zikir dalam keadaan dan situasi apapun, sehingga mampu memanfaatkan gejala, proses, dan sarana alamiah ini untuk kemaslahatan dan kebahagiaan seluruh umat manusia. Ulul albāb adalah intelektual muslim yang tangguh, yang tidak hanya memiliki ketajaman analisis obyektif, tatapi juga subyektif. ${ }^{6}$ Tujuan pendidikan $\bar{u} l u l$ albāb, adalah menyiapkan peserta didik yang memiliki beberapa karakteristik tersebut.

Menurut UU Nomor 20/2003 tentang Sistem Pendidikan Nasional pasal 36 ayat (2), bahwa kurikulum pada semua jenjang dan jenis pendidikan dikembangkan dengan prinsip diversifikasi sesuai dengan satuan pendidikan, potensi daerah dan peserta didik. Dalam pasal 38 ayat (3) dijelaskan bahwa kurikulum pendidikan tinggi dikembangkan oleh perguruan tinggi yang bersangkutan dengan mengacu pada standar nasional pendidikan untuk setiap program studi.

Berdasarkan UU tersebut, menjadikan konsep ūlul albāb sebagai asumsi dasar dalam pengembangan pendidikan di UIN Maliki Malang merupakan perwujudan dari prinsip diversifikasi, sehingga dapat dibenarkan selama tetap memperhatikan standar nasional

\footnotetext{
${ }^{6}$ Saefuddin, Desekularisasi Pemikiran ..., hlm. 34.
} 
pendidikan. Untuk mewujudkan tujuan pendidikan tersebut, diperlukan struktur keilmuan yang jelas.

Gambar 1

Struktur Keilmuan Dikotomik

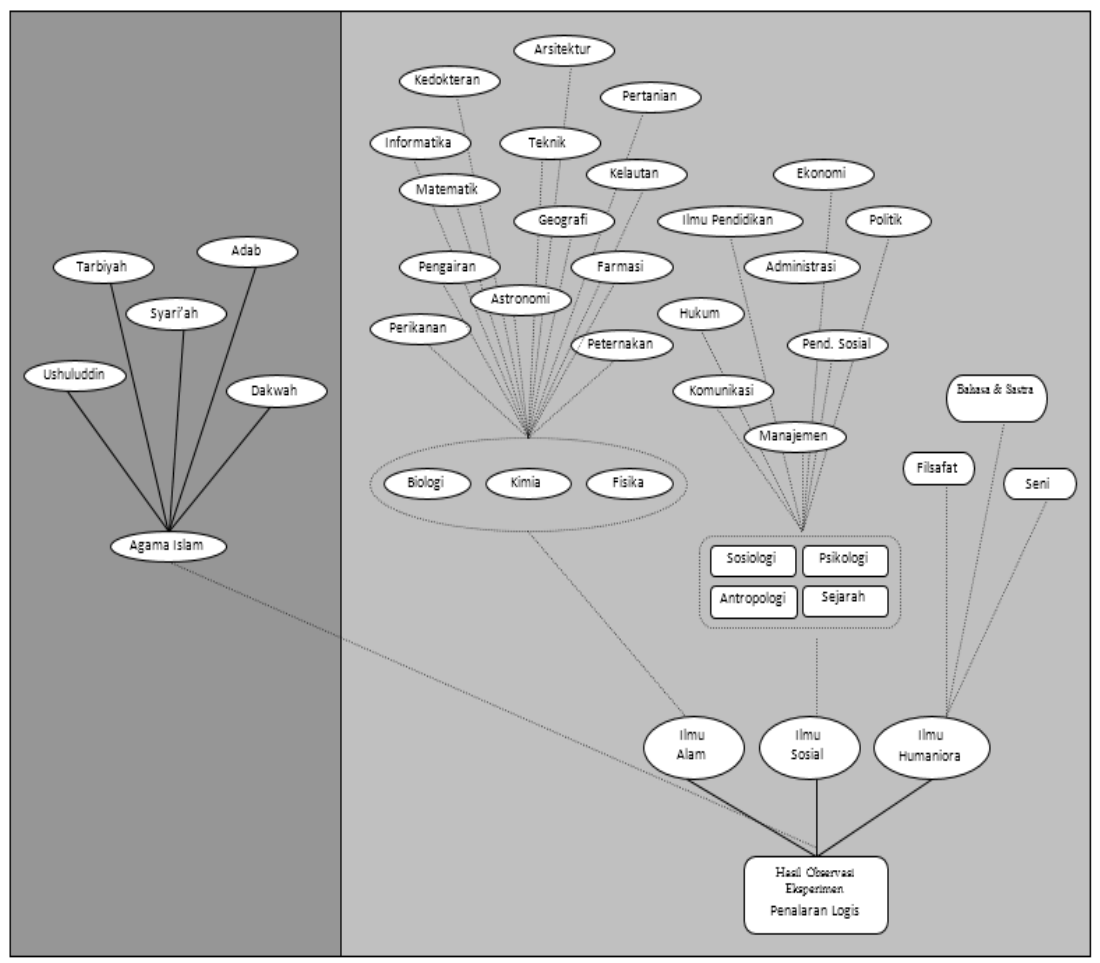

1. Struktur Keilmuan Integratif

Struktur keilmuan UIN Maliki Malang dibangun berdasarkan prinsip universalitas ajaran Islam yang digambarkan sebagai pohon ilmu yang rindang dan kokoh. Gagasan Imam Suprayogo tentang "Pohon Ilmu" yang dijadikan sebagai blue print pengembangan ilmu di UIN Maliki Malang, memang ada sedikit perdebatan pada tataran epistemologinya. Menurut Muhaimin, sumber ilmu pengetahuan itu pada dasarnya datangnya dari Allah. Allah menciptakan alam semesta (ayat kauniyyah) dan al-Quran serta al-Hadis (ayat qauliyyah). Oleh karenanya kedua sumber tersebut saling menjelaskan dan tidak bertentangan dengan berbagai ilmu pengetahuan tentang hakikat kebenaran. Selama ini orang berpikir di sayap kanan dan kiri disebut dikotomik. 
Berdasarkan temuan penelitian, menurut Imam Suprayogo ada dua tawaran terkait dengan peletakan al-Quran sebagai sumber ilmu pengetahuan. Pertama, meletakkan alQuran sebagai konsep dasar atau inspirasi yang kemudian dikembangkan melalui berbagai riset ilmiah (lihat gambar 1). Kedua, meletakkan al-Quran (fenomena naqliyah) dan alam (fenomena kauniyyah) menjadi dua sumber yang setara bagi bangunan ilmu pengetahuan (lihat gambar 2).

Gambar 2

Bangunan Keilmuan Integratif

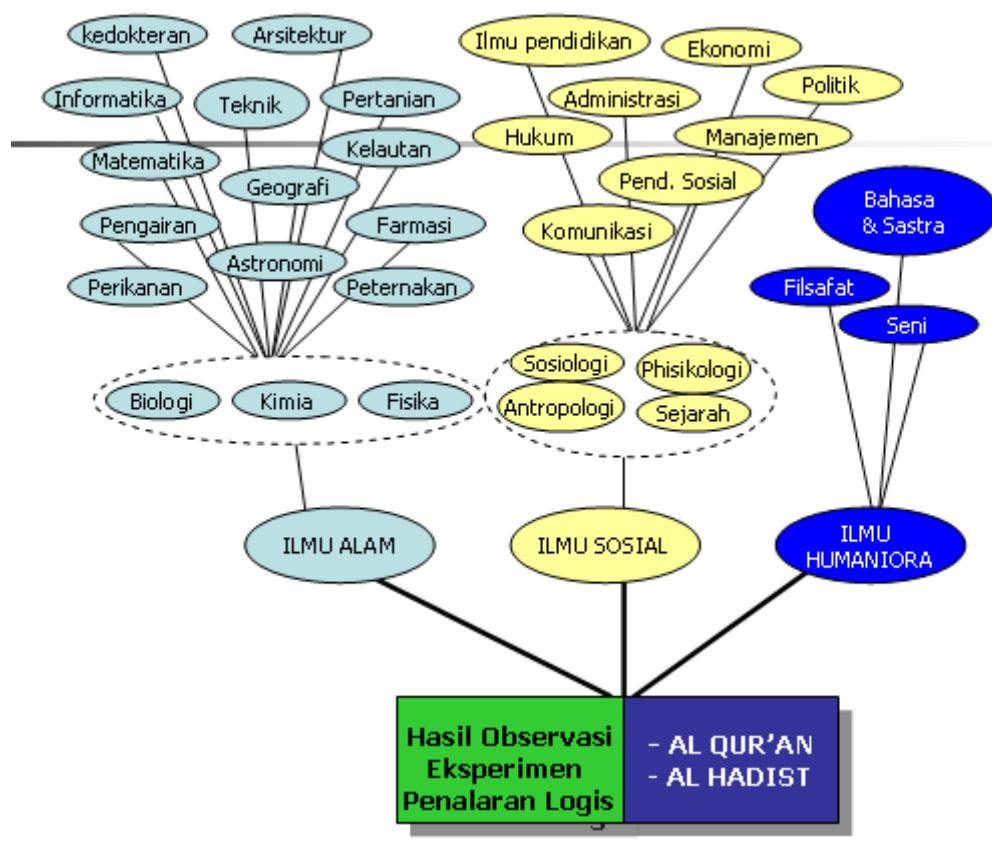

Pada gambar satu muncul sebuah pertanyaan, apa yang dimaksud dengan al-Quran sebagai sumber ilmu pengetahuan? Kalau yang dimaksud adalah al-Quran sebagai salah satu makhluk Tuhan yang dapat dijadikan sebagai salah satu sumber ilmu pengetahuan maka dapat dibenarkan, karena Allah juga menciptakan fenomena lain yang bersifat kauniyyah (alam semesta) dan fenomena nafsiyyah (manusia) yang juga memiliki kontribusi besar sebagai sumber ilmu pengetahuan, teknologi dan seni. 
Bagaimana bila al-Quran dijadikan sebagai sumber inspirasi, pertanyaan berikutnya adalah apakah seorang ilmuwan yang menggagas teori dari inspirasi yang melalui renungan tentang fenomena di sekitarnya tidak atau kurang Islami teorinya dari teori seorang ilmuwan yang mendapat inspirasi langsung dari al-Quran? Kalau dikatakan "ya", pertanyaan berikutnya adalah dengan ukuran apa sebuah teori dikatakan Islami dan tidak Islami? Apakah sebuah teori Islami semata-mata didasarkan atas sumber inspirasinya ataukah kejujuran ilmiah yang diemban oleh seorang ilmuwan sekalipun dia tidak memperoleh inspirasi dari al-Quran, atau bahkan mungkin dia tidak bisa membaca al-Quran? Kalau di dalam salah satu ayat al-Quran ditemukan istilah ḍarrah yang selama ini dijadikan pembenar atas teori atom, maka pertanyaannya adalah apakah itu bersifat justifikatif ataukah inspiratif, jika faktanya bahwa Niels Bohr menemukan atom tidak terinspirasi oleh ayat al-Quran. Jika faktanya hanyalah justifikatif, sering kali aplikasi praktis Islamization of knowledge adalah upaya mencari ayat atau hadis untuk menjustifikasi pengetahuan tertentu yang dianggap Islami, maka gugurlah klaim al-Quran sebagai sumber inspirasi ilmu pengetahuan. Kalau kemudian dikatakan bahwa ilmu pengetahuan dibangun dari proses riset ilmiah atas fakta empiris, lalu apa makna pernyataan al-Quran sebagai sumber ilmu pengetahuan tersebut? Oleh sebab itu, ada sekian banyak problem epistemologis yang terkait dengan dua hal tersebut. Cara pandang yang berbeda akan menghasilkan rumusan pengetahuan yang berbeda, baik mengenai alam maupun alQuran. ${ }^{7}$

Realitas keilmuan seperti ini semakin memperlihatkan bahwa aktivitas ilmiah adalah aktivitas ilmiah, dia tidak bisa disekat berdasarkan keyakinan-keyakinan religius apapun. Seorang ahli fisika secara keilmuan tidak harus bisa membaca al-Quran. Kalaupun bisa lebih baik sejauh rumusannya menggunakan prosedur keilmuan yang benar, bisa diterima, dan ini sama sekali tidak memiliki konsekuensi teologis Islam atau nonIslam. Sejauh ilmu-ilmu keislaman, seperti tafsir

${ }^{7}$ Zainul Hamdi, "Menilai Gagasan Ulang Islamisasi Ilmu sebagai Blue Print Pengembangan Keilmuan UIN", dalam Wahyudi, Integrasi Ilmu dan Agama ..., hlm. 186-188. 
dipahami sebagai satu ilmu, maka keharusan bagi seseorang untuk mengerti ilmu nahwu, ilmu saraf, ilmu mantiq, ilmu balagah, ilmu ma'ani ataupun bahasa Arab, dan berbagai perangkat rumpun ilmu-ilmu keislaman yang lain bukan sebagai keharusan teologis, tapi keharusan ilmiah, bahwa seseorang bisa mempelajari tafsir kalau dia memahami kaidah-kaidah bahasa Arab dan beberapa ilmu pendukungnya.

Jika kita menggagas suatu teori ilmiah yang dianggap berdasarkan al-Quran dan Hadis, maka itu hanyalah salah satu varian dari sekian banyak pandangan yang berbeda-beda. Sebuah ayat tidak bisa memberi priveles apapun terhadap teori kita atas teori lain yang tidak ada ayatnya. Bahkan menurut Hamdi ketika ada dua orang ilmuwan yang mendapatkan inspirasinya dari al-Quran, bisa jadi dia akan mengkonstruksi teori yang berbeda. Hal ini karena inspirasi Qur'ani lahir bukan sebagai sesuatu yang given, tapi disebabkan oleh cara seseorang memandang dan membaca alQuran. $^{8}$

Dalam hal ini, seperti diungkapkan Ahmad Tafsir bahwa ilmu adalah milik Allah, sehingga teori-teori yang didapat dari mempelajari al-Quran tidak mungkin berlawanan dengan teori-teori yang didapat dari mempelajari al-kaun (alam semesta) sebab dua kelompok teori itu adalah teori dari Tuhan, karena tidak ada perlawanan dalam pengetahuan Tuhan. ${ }^{9}$

Berdasarkan pemikiran tersebut, bahwa konsep integrasi ilmu umum dan ilmu agama yang digunakan sebagai blue print pengembangan keilmuan UIN Malang sebenarnya sebagai upaya untuk menghilangkan dikotomi keilmuan tersebut. ${ }^{10}$ Meskipun para ilmuwan dahulu seperti Ibn Khaldun membagi ilmu menjadi dua yaitu ilmu naqliyyah dan

\footnotetext{
${ }^{8}$ Hamdi, Integrasi Ilmu ..., hlm. 186-188.

${ }^{9}$ Ahmad Tafsir, Filsafat Pendidikan Islami Integrasi Jasmani, Rohani dan Kalbu Memanusiakan Manusia, (Bandung: Remaja Rosdakarya, 2010), hlm. 111.

${ }_{10}$ Mengenai konsep integrasi ilmu umum dan ilmu agama masingmasing UIN di Indonesia memiliki konsep keilmuan yang berbeda tetapi dengan tujuan yang sama. Misalnya UIN Syarif Hidayatullah Jakarta dengan konsep Integrasi Ilmu, UIN Sunan Kalijaga Yogyakarta dengan Jaring LabaLaba, UIN Bandung dengan konsep Wahyu Memandu Ilmu.
} 
ilmu 'aqliyah. Imam Gazali membuat klasifikasi ilmu menjadi ilmu-ilmu agama atau ukhrawi yang disebut fardu 'ain dan ilmu-ilmu umum atau duniawi disebut fardu kifayah. Kedua ilmu tersebut menurut al-Gaazali wajib ditempuh dan dimiliki oleh umat Islam. Menurut Azyumardi Azra klasifikasi ilmu tersebut bukan dimaksud mendikotomi ilmu antara satu dengan yang lain, tetapi hanya sekadar klasifikasi. Dalam konteks ini ilmu agama Islam merupakan salah satu saja dari berbagai cabang ilmu secara keseluruhan. ${ }^{11}$

Dengan demikian, Islamic knowledges (al-'ulüm al-Islämiyyah) yang dikembangkan oleh UIN Maliki Malang adalah ilmu pengetahuan yang dibangun berdasarkan ajaran Islam yakni al-Quran dan Hadis, sekaligus pengetahuan yang sama dibangun berdasarkan hasil observasi, eksperimentasi, dan penalaran logis. Jika al-Quran dan Hadis diletakkan pada posisi sumber ilmu, maka tidak akan terjadi cara pandang ilmu yang dikotomik dan justru merendahkan posisinya sebagai kitab suci. Sudah barang tentu sebagai konsekuensi al-Quran yang bersifat universal masih diperlukan sumber pengetahuan lain yang bersifat teknis, yaitu ilmu pengetahuan yang diperoleh melalui observasi, eksperimen dan penalaran logis.

Paparan di atas menegaskan bahwa konsep integrasi keilmuan UIN Malang, menegasikan Islam sebagai paradigma dalam berbagai kajian ilmu pengetahuan. Melalui pemahaman seperti ini ayat-ayat qauliyyah yang berhubungan dengan ilmu pengetahuan meniscayakan untuk dielaborasi secara saintifik sesuai dengan kebutuhan kerja ilmiah yang dibangunnya. Seperti diungkapkan Osman Bakar, al-Quran bukanlah kitab sains. Tetapi ia memberikan pengetahuan tentang prinsip-prinsip sains, yang selalu dikaitkannya dengan pengetahuan metafisik dan spiritual. ${ }^{12}$ Gagasan tersebut sesuai dengan pendapat Endang Saefuddin Ansari bahwa al-Quran atau ayat Qur'aniyyah tidak lain adalah pembukuan segenap alam semesta atau ayat kauniyyah dalam satu al-Kitab. Kedua ayat Allah yaitu ayat Qurāniyah dan ayat kauniyyah itu

\footnotetext{
${ }^{11}$ Azra, Pendidikan Islam ..., hlm. xii-xiv.

${ }^{12}$ Bakar, Tauhid dan Sains ..., hlm. 151.
} 
saling menafsirkan. ${ }^{13}$ Dalam proses pengilmuan Islam Kuntowijoyo menawarkan dua metodologi, yaitu integralisasi dan objektivikasi. ${ }^{14}$

2. Kurikulum integratif yang dikembangkan

Untuk merealisasikan struktur keilmuan dengan metafora pohon ilmu, kurikulum UIN Maliki Malang diintegrasikan dengan program Ma'had Sunan Ampel al-Aly. Berdasarkan struktur keilmuan tersebut, UIN Maliki Malang mewajibkan seluruh mahasiswa tanpa melihat jurusan atau program studi apa, untuk menguasai pondasi atau akar keilmuan lebih dahulu terdiri dari; 1) Bahasa Arab dan Bahasa Inggris, 2) Filsafat, 3) Ilmu Kealaman, 4) Ilmu Sosial, dan 5) Pendidikan Pancasila dan Kewarganegaraan, sebelum mengkaji ajaran Islam (pada pohon ilmu digambarkan sebagai sebuah batang), meliputi; 1) al-Quran dan al-Sunnah, 2) Sirah Nabawiyah dan Sejarah Peradaban Islam, 3) Pemikiran Islam terdiri atas; Teologi, Fiqih, dan Tasawuf, 4) Pemahaman terhadap masyarakat Islam. Selanjutnya mahasiswa mengkaji keilmuan sesuai dengan pilihan dan jurusan serta program studi masingmasing (yang digambarkan sebagai sebuah dahan dan ranting).

Struktur kurikulum tersebut bila dikaitkan dengan realitas sejarah pengembangan perguruan tinggi Islam didorong oleh beberapa tujuan, yaitu; 1) untuk melaksanakan pengkajian dan pengembangan ilmu-ilmu agama Islam pada tingkat yang lebih tinggi secara lebih sistematis dan terarah; 2) untuk melaksanakan pengembangan dan peningkatan dakwah Islam; dan 3) untuk melakukan reproduksi dan kaderisasi ulama dan fungsionaris keagamaan, baik pada birokrasi negara maupun sektor swasta, serta lembaga-lembaga sosial, dakwah, pendidikan dan sebagainya. ${ }^{15}$ Maka pemahaman akan tujuan yang pertama berimplikasi pada tujuan kedua dan ketiga tersebut di atas.

Tujuan kedua adalah untuk melaksanakan pengembangan dan peningkatan dakwah Islam. Makna dakwah Islam bukan

13 Endang Saifuddin Anshari, Ilmu, Filsafat dan Agama, (Surabaya: Bina Ilmu, 1987), hlm. 176.

${ }^{14}$ Kuntowijoyo, Islam sebagai Ilmu ...., hlm. 49.

${ }^{15}$ Azra, Pendidikan Islam ..., hlm. 170. 
lagi tereduksi menjadi dakwah dalam arti mengomunikasikan al-'ulüm al-naqliyah (perennial knowledge) saja, yang mencakup: studi al-qur'an, studi hadis, sirah nabawiyyah, tauḥid, ușūl fiqh dan fiqh, bahasa Arab, serta bidang-bidang studi tambahan yang meliputi; Metafisika Islam, Perbandingan Agama, dan Sejarah Kebudayaan Islam. Tetapi menurut Bilgrami juga bagaimana al-'ulüm al-naqliyyah (perennial knowledge) memberi spirit dan landasan, serta ancangan bagi pengembangan al-'ulum al-aqliyyah (acquired knowledge), yang mencakup: 1) Arts (ilmu-ilmu imajinatif), seperti, kesenian dan arsitektur Islam, bahasa-bahasa, kesusasteraan; 2) ilmu-ilmu intelektual, yang meliputi: ilmuilmu sosial, filsafat, pendidikan, ekonomi, ilmu politik, sejarah, peradaban Islam, geografi, sosiologi, linguistik, psikologi, antropologi; 3) ilmu-ilmu kealaman, yang meliputi: filsafat ilmu pengetahuan, matematika, statistika, fisika, kimia, biologi, astronomi, ilmu-ilmu angkasa luar dan sebagainya; 4) ilmu-ilmu terapan, yang meliputi teknik dan teknologi, kedokteran, pertanian dan kehutanan; 5) ilmu-ilmu praktis, meliputi: perdagangan, ilmu-ilmu administrasi, ilmuilmu perpustakaan, ilmu-ilmu kerumahtanggaan, ilmu komunikasi dan sebagainya. ${ }^{16}$

Sedangkan tujuan ketiga adalah untuk melakukan reproduksi dan kaderisasi ulama. Pemahaman tentang ulama bukan lagi terbatas pada mereka yang menguasai al-'ulüm alnaqliyyah (perennial knowledge), tetapi juga mereka yang menguasai al-'ulum al-aqliyah (acquired knowledge), serta menjadikan al-'ulüm al-naqliyyah (perennial knowledge) sebagai landasan, spirit serta ancangan bagi pengembangan al-'ulüm al-aqliyyah (acquired knowledge) tersebut.

Dilihat dari sudut pandang tersebut, menurut Muhaimin, ${ }^{17}$ studi keislaman akan mengalami pemekaran makna, yaitu: pertama, studi Islam sebagai sumber ajaran yang merupakan wahyu Ilahi yang terhimpun dalam al-Quran dan Hadis. Dalam bidang yang pertama ini, studi Islam bertumpu pada studi kewahyuan yang diwujudkan dalam bentuk mata kuliah seperti studi al-Quran, studi hadis dan lain-lainnya.

\footnotetext{
${ }^{16}$ Bilgrami dan Ashraf, Konsep Universitas Islam ..., hlm. 14-20.

${ }^{17}$ Zainuddin, dkk. (ed), Memadu Sains dan Agama ..., hlm. xxvii-xxviii.
} 
Kedua, studi Islam sebagai bagian dari pemikiran atau bagian dari fiqh dalam arti luas. Dalam sejarah pemikiran Islam setidak-tidaknya ada lima bidang pemikiran Islam yang menonjol, yaitu: akidah-teologi (ilmu kalam), hukum dalam arti luas (syari' 'ah), filsafat, akhlak-sufisme (tasawuf), ilmu pengetahuan teknologi seni (al-'ulüm al-dunyawiyah), yang mencakup bidang-bidang yang mencakup luas mulai dari IPA, matematika hingga teknik arsitektur, informatika dan astronomi. Ketiga, studi Islam sebagaimana yang dialami, diamalkan dan diterapkan dalam kehidupan. Dengan bersumber pada al-Quran dan Hadis, kemudian dijabarkan dalam berbagai pemikiran, ajaran Islam lalu diamalkan dan diterapkan oleh umat Islam hingga membentuk peradaban Islam.

Kajian yang dikembangkan UIN Maliki Malang untuk penyiapan ulül albāb tidak sekedar menekankan pada pengembangan ilmu-ilmu pengetahuan agama Islam dalam arti al-'ulüm al-naqliyah (bersumber wahyu), tetapi sekaligus menyangkut kajian al- 'ulum al-aqliyah (bersumber pada alam semesta) yang bersifat empiris, selaras dengan karakteristik ulūl albāb tersebut di atas. Karena itulah, pengembangan al'ulūm al-naqliyah semata dianggap kurang relevan lagi dengan pengembangan ilmu pengetahuan dan tuntutan pembangunan nasional, karena bersifat sangat sektoral, hanya memenuhi satu sektor tertentu dalam kehidupan Islam di Indonesia, yaitu memenuhi kebutuhan sarjana-sarjana yang mendapatkan pengetahuan tinggi mengenai agama Islam. Dengan demikian konsep ulül albāb yang diharapkan adalah mereka yang menguasai iptek dan sekaligus hidup di dalam nilai-nilai agama Islam.

Berdasarkan buku Pedoman Pendidikan Fakultas Tarbiyah UIN Maliki Malang tahun 2012, Mata Kuliah Dasar Keuniversitasan yang harus ditempuh oleh semua mahasiswa UIN Maliki Malang, terdiri dari: a) Pendidikan Kewarganegaraan, b) Bahasa Indonesia, c) Bahasa Inggris, d) Ilmu Alamiah Dasar, e) Ilmu Budaya Dasar, f) Filsafat Ilmu, g) Studi al-Qur'an, h) Studi al-Hadis, i) Studi Fiqh, j) Akhlak/Tasawuf, k) Sejarah Peradaban Islam, 1) Teologi Islam, m) Maharat al-Istima' I, II, n) Maharat al-Kalām I, II, 
o) Maharat al-Qiraah I, II, p )Maharat al-Kitabah I, II, q) Tarbiyah Ulül Albāb. ${ }^{18}$

Untuk tercapainya pengembangan pada mata kuliah dasar di universitas tersebut, maka menurut Muhaimin harus dibarengi dengan pembiasaan dan pembelajaran di ma'had. Oleh karena itulah, struktur kurikulum mata kuliah dasar keuniversitasan UIN Malang diintegrasikan dengan pembelajaran di Ma'had Sunan Ampel al-Aly, dengan menjadikan sertifikat kelulusan ta'lim al-afkar al-Islämi dan ta'lim al-Qurān sebagai prasarat untuk memprogram studi keislaman, dan sebagai prasarat ujian komprehensif. Bagi mahasiswa yang belum lulus, maka mahasiswa tersebut dapat memprogram mata kuliah studi keIslaman dengan syarat tetap mengikuti program remidial ta'tim ma'had sampai yang bersangkutan dinyatakan lulus, dan nilai kelulusan program remidial tersebut menjadi syarat penerbitan nilai akhir untuk mata kuliah studi keislaman yang diprogram. ${ }^{19}$

Program sabāh al-lugah yang dilaksanakan di ma'had, PKPBA dan PKPBI dilaksanakan di UIN Maliki Malang untuk memperkuat kemampuan bahasa Arab dan Inggris mahasiswa, yang pada gilirannya dapat digunakan sebagai alat untuk mengkaji sumber ajaran Islam dan juga disiplin ilmu masing-masing. Seperti diungkapkan Karel A. Steenbrink bahwa penguasaan bahasa Arab juga penting di luar penguasaan Agama. ${ }^{20}$ Sedangkan pembinaan kajian al-Quran bagi dosen melalui kegiatan di LKQS, pembinaan membaca al-Quran bagi karyawan melalui kegiatan tậsin al-Qurān di HTQ.

Pembelajaran di Ma'had Sunan Ampel al-Aly adalah bagian integral dari sistem kelembagaan dan pendidikan UIN Maliki Malang. Karena itulah, pembelajaran di ma'had diatur oleh Pembantu Rektor Bidang Akademik melalui mudir dan pengurus ma'had, baik menyangkut kurikulum, perkuliahan, dan sistem evaluasi. Hal ini untuk mengukur tingkat keberhasilan pembelajaran ta'Tim al-afkār al-Islämi dan ta'Tim al-Qurān.

${ }^{18}$ Pedoman Pendidikan Fakultas Tarbiyah UIN Maliki Malang, 2010, hlm. 35-36.

${ }^{19}$ Pedoman Pendidikan UIN Maliki Malang, 2010, hlm. 53.

${ }^{20}$ Steenbrink, Pesantren Madrasah ..., hlm. 176. 
Sebagaimana diungkapkan oleh Hasyim bahwa pesantren dapat dijadikan sebagai sistem pendidikan alternatif yaitu, pertama, apabila pesantren tidak menolak perkembangan paradigma sains dan teknologi modern, dengan tanpa meninggalkan nilai-nilai paradigma keislaman. Kedua, harus ada sebuah kurikulum yang seimbang antara trilogi keilmuan yang berlandaskan Islam; 1) Islamic natural sciences; 2) Islamic social science; 3) religion sciences. Diharapkan dengan kurikulum ini, santri dapat menggabungkan antara pengetahuan, keterampilan dan sikap. ${ }^{21}$

\section{Gambar 3}

Integrasi Kurikulum UIN dengan Ma'had Sunan Ampel al-Aly

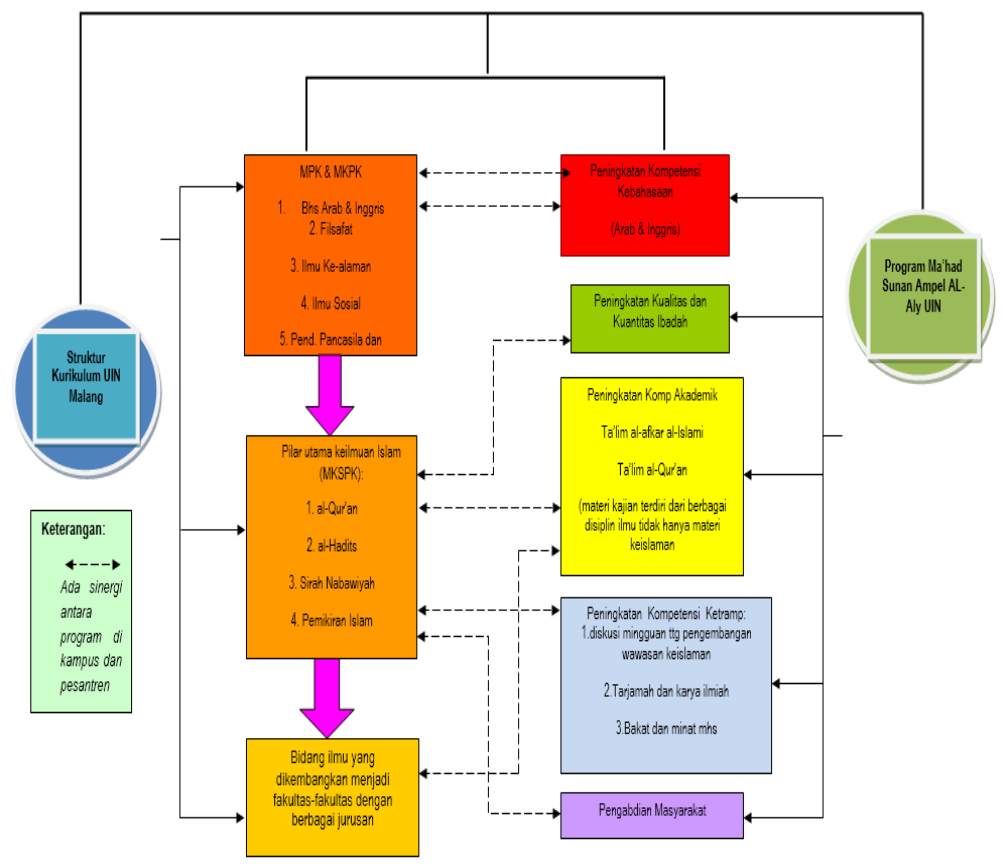

Implementasi kurikulum integratif di UIN Maliki Malang menurut peneliti, menggunakan pendekatan kebutuhan sosial (social demand approach) yang diajukan Gorton. Dengan alasan dalam rangka mewujudkan visi dan misi UIN Maliki

${ }^{21}$ M. Affan Hasyim, "Menatap Masa Depan Pesantren dalam Menyongsong Indonesia Baru”, dalam Menggagas Pesantren ..., hlm. 231. 
Malang dengan empat pilar yaitu; 1) Kedalaman Spiritual; 2) Keluhuran Akhlak; 3) Keluasan Ilmu Pengetahuan; dan 4) Kematangan Profesional, maka model pembelajaran di UIN Maliki Malang adalah dengan mengintegrasikan kurikulum ma'had dengan kurikulum UIN. Di samping itu, Muhaimin juga menambahkan bahwa, pengembangan kurikulum di UIN Malang menggunakan empat pendekatan dengan mempertimbangkan karakteristik tujuan dan isi kurikulumnya, yaitu; 1) pendekatan subyek akademik; 2) pendekatan humanistik; 3) pendekatan teknologik; 4) pendekatan rekonstruksi sosial. Skema kurikulum integratif Ma'had 'Āly dan UIN Maliki Malang dapat dilihat pada gambar 3.

\section{Penutup}

Berdasarkan paparan data di atas dapat disimpulkan bahwa struktur keilmuan UIN Maliki Malang dengan metafora pohon ilmu bersifat dialogis-konsultatif. Kurikulum UIN Maliki Malang mengintegrasikan program Ma'had Sunan Ampel Al-Aly dengan kurikulum UIN Maliki Malang, dengan menjadikan sertifikat kelulusan ta'Tim al-afkār al-Islämì dan ta'Tim al-Qurān sebagai prasarat untuk memprogram studi keislaman dan sebagai prasarat ujian komprehensif. Pembinaan kajian al-Quran bagi dosen melalui kegiatan di LKQS dan pembinaan membaca al-Quran bagi karyawan melalui kegiatan tahsin al-Qurān dan pembinaan hafalan al-Quran mahasiswa di HTQ.

Langkah-langkah yang dapat digunakan untuk menerapkan pembelajaran berparadigma Qur'ani yaitu; a) memetakan konsep keilmuan umum dan keilmuan agama; b) memadukan konsep keilmuan umum dan keilmuan agama; c) mengelaborasi ayat-ayat al-Quran yang relevan secara saintifik. Tradisi ma'had seperti salat berjama'ah, zikir bersama, khatm al-qur'ān dan hifz al-qur'ān, puasa senin dan kamis, infaq dan shadaqah untuk membentuk karakter mahasiswa dan mengembangkan kultur Islami di kalangan civitas akademika UIN Maliki Malang. Tradisi pesantren juga dikembangkan sebagai wahana pendidikan kepemimpinan umat dan pengembangan kecakapan berbahasa Arab dan Inggris. Dengan demikian, model pengorganisasian kurikulum UIN Maliki Malang menggunakan correlated curriculum.

\section{Kepustakaan}


Abdullah, Amin, "Imam Suprayogo dan Ki Hajar Dewantara: Pelopor Pendidikan yang Teguh Pendirian dan Visioner", dalam Ahmad Barizi (ed.), Membangun Pendidikan dalam Bingkai Islam Lintas Batas, (Malang: UIN Malang Press, 2011).

A'la, Abd., Pembaruan Pesantren,(Yogyakarta: LKiS, 2006).

Al-Attas, Syed Muhammad Naquib, Islam dan Sekularisme, (Bandung: Pustaka, 1981).

Al-Faruqi, Ismail Raji, Islamisasi Pengetahuan, terj. Anas Mahyuddin, (Bandung: Pustaka, 1984).

Ahmad Tafsir, Filsafat Pendidikan Islam Integrasi Jasmani, Rohani, dan Kalbu Memanusiakan Manusia, (Bandung: Remaja Rosdakarya, 2010).

Anwar, Miski, "Tradisi Pesantren di Tengah Transformasi Sosial", dalam A.Z. Fanani dkk. (peny.), Menggagas Pesantren Masa Depan Geliat Suara Santri Untuk Indonesia Baru, (Yogyakarta: Qirtas, 2003).

Asrohah, Hanun, Kelembagaan Pesantren Asal-usul dan Perkembangan Pesantren di Jawa, (Jakarta: Bagian Proyek Peningkatan Informasi Penelitian dan Diklat Keagamaan, 2004).

Azizy, A. Qodri Abdillah, "Pengantar: Memberdayakan Pesantren dan Madrasah", dalam Ismail SM, Nurul Huda dan Abdul Khaliq (ed.). Dinamika Pesantren dan Madrasah, (Yogyakarta: Pustaka Pelajar, 2002).

Azra, Azyumardi, Pendidikan Islam Tradisi dan Modernisasi Menuju Milenium Baru, (Jakarta: Logos Wacana Ilmu, 1999).

Bagir, Zainal Abidin, "Bagaimana Mengintegrasikan Ilmu dan Agama?", dalam Jarot Wahyudi, dkk. (editor), Integrasi Ilmu dan Agama: Interpretasi dan Aksi, (Yogyakarta: MYIACRCS dan Suka Press, 2005).

Barbour, Ian G., Juru Bicara Tuhan antara Sains dan Agama, terj. E.R. Muhammad, (Bandung: Mizan, 2002).

Barizi, Ahmad (ed.), Holistik Pemikiran Pendidikan A. Malik Fadjar, (Jakarta: Raja Grafindo Persada, 2005). 
Bilgrami, Hamid Hasan dan Sayid Ali Ashraf, Konsep Universitas Islam, terj. Machnun Husein, (Yogyakarta: Tiara Wacana, 1999).

Dhofier, Zamakhsyari, Tradisi Pesantren, Sudi Tentang Pandangan Hidup Kyai, (Jakarta: LP3ES, 1982).

Djubaedi, Dedi, "Pemaduan Pendidikan Pesantren-Sekolah: Telaah Teoritis dalam Perspektif Pendidikan Nasional" dalam Marzuki Wahid dkk (ed.). Pesantren Masa Depan Wacana Pemberdayaan dan Transformasi Pesantren. (Bandung: Pustaka Hidayah, 1999).

Gorton, School Administration Challenge and Opportunity for Leadership, (New York: Brown Company, 1976).

Haedari, M. Amin dan Abdullah Hanif (ed.), Masa Depan Pesantren dalam Tantangan Modernitas dan Tantangan Kompleksitas Global, (Jakarta: IRD Press, 2004).

Hamdi, Zainul, "Menilai Ulang Gagasan Integrasi Ilmu Pengetahuan sebagai Blue Print Pengembangan Keilmuan UIN", dalam Zainal Abidin Bagir, dkk (editor), Integrasi Ilmu dan Agama Interpretasi dan Aksi (Yogyakarta: MYIA-CRCS dan Suka Press, 2005).

Hamim, Thoha, Islam dan NU: Di Bawah Tekanan Problematika Kontemporer: Dialektika Kehidupan Politik, Agama, Pendidikan dan Sosial Masyarakat Muslim. (Surabaya: Diantama, 2004).

Hidayat, Komarudin, "Menimbang Kurikulum 1997" dalam Perta, (vol. I no. 9/1997), hlm. 12-17.

Hirokoshi, Hiroko, Kyai dan Perubahan Sosial, terj. Umar Basalim dan Andi Muarly Sunrawa, (Jakarta: LP3ES, 1987).

Kuntowijoyo, Paradigma Islam Interpretasi untuk Aksi, (Bandung: Mizan, 1991).

Kuswanjono, Arqom, Integrasi Ilmu dan agama Perspektif Filsafat Mulla Sadra, (Yogyakarta: Lima, 2010).

Ma'arif, Syafi'i, Peta Bumi Intelektualisme Islam di Indonesia, (Bandung: Mizan, 1993).

Mahzar, Armahedi, "Integrasi Sains dan Agama: Model dan Metodologi”, dalam Jarot Wahyudi, Integrasi Ilmu dan Agama: Interpretasi dan Aksi, (Yogyakarta: MYIA-CRCS dan Suka Press, 2005). 
Mastuhu, Memberdayakan Sistem Pendidikan Islam, (Jakarta: Logos, 1999).

-----, Dinamika Sistem Pendidikan Pesantren, (Jakarta: INIS, 1994).

Muhaimin, Arah Pengembangan Pendidikan Islam Pemberdayaan, Pengembangan Kurikulum Hingga Redifinisi Islamisasi Pengetahuan, (Bandung: Nuansa, 2003).

------, Wacana Pengembangan Pendidikan Islam, (Yogyakarta: Pustaka Pelajar, 2003).

Pedoman Pendidikan Universitas Islam Negeri (UIN) Malang Tahun Akademik 2011/2012.

Qomar, Mujamil, Pesantren Dari Transformasi Metodologi Menuju Demokratisasi Institusi, (Jakarta: Erlangga, t.t.).

Rahardjo, Dawam (ed.), Pesantren dan Pembaharuan, (Jakarta: LP3ES, 1974).

Saefuddin, A.M., et.al., Desekularisasi Pemikiran: Landasan Islamisasi, (Bandung: Mizan, 1998).

Suprayogo, Imam, "Relasi Kajian Islam dan Sains dalam Merespon Tantangan Lokal dan Global", Annual Conference Kajian Islam (Bandung, 26-30 November 2006).

------, Universitas Islam Unggul Refleksi Pemikiran Pengembangan Kelembagaan dan Reformulasi Paradigma Keilmuan Islam, (Malang: UIN Malang Press, 2009).

------, Hubungan antara Perguruan Tinggi dan Pesantren, (Malang: UIN Malang Press, 2007).

Tholkhah, Imam, dkk., Membuka Jendela Pendidikan Mengurai Akar Tradisi dan Intregasi Keilmuan Pendidikan Islam, (Jakarta: Raja Grasindo Persada, 2004).

Wahid, Marzuki, "Ma'had Aly: Nestapa Tradisionalisme dan Tradisi Akademik yang Hilang", Jurnal Istiqro', (vol. 04, no. 01/2006), hlm. 96-107.

Zainiyati, Husniyatus Salamah, "Pesantren Mahasiswa Transformatif sebagai Upaya Pemberdayaan Mahasiswa PTAI", Jurnal Menara Tebuireng, (vol. 3, no.1/September 2006), hlm. 92-102.

Ziemeck, Manfred, Pesantren dalam Perubahan Sosial, (Jakarta: P3M, 1986). 
